\title{
Protection of Animals against Cruelty: Transport of Cattle, Sheep, Goats and Pigs
}

\author{
J. DOUSEK ${ }^{1}$, V. VEČEREK ${ }^{2}$, O. VALCL ${ }^{1}$, P. CHLOUPEK ${ }^{2}$, V. PIŠTĚKOVÁ ${ }^{2}$ \\ ${ }^{1}$ State Veterinary Administration, Prague, Czech Republic \\ ${ }^{2}$ University of Veterinary and Pharmaceutical Sciences, Brno, Czech Republic
}

Received April 5, 2002

Accepted November 18, 2002

Abstract

Dousek J., V. Večerek, O. Valcl, P. Chloupek, V. Pištěková: Protection of Animals against Cruelty: Transport of Cattle, Sheep, Goats and Pigs. Acta Vet. Brno 2002, 71: 555-562.

The inspections carried out by the officers of the State Veterinary Administration (SVA) within the framework of surveillance of animal transport revealed that cases of violation of the principles of animal protection may and do occur. Therefore evaluation was made of transport in selected groups of cattle, sheep, goats and pigs in the Czech Republic during the period of 1996 to 2001. Each inspection was assessed using the following scale: (1) animal protection requirements fulfilled, (2) animal protection requirements partially fulfilled and veterinary measures for the improvement of animal protection imposed, (3) failure to fulfil animal protection requirements. The proportion of the situations of when animal protection requirements were partially met and veterinary measures were imposed to improve the level of protection in cattle varied between $0.00 \%$ and $1.35 \%$ of the total number of the inspections carried out. In sheep and goats this situation occurred only sporadically. In pigs the proportion was $0.22 \%$ to $2.22 \%$ of the total number of the inspections carried out. The proportion of the situations when failure to fulfil animal protection requirements in cattle occurred varied between $0.00 \%$ and $0.83 \%$ of the total number of the inspections carried out. In sheep this situation occurred in a single case only and in goats no such situation was recorded. In pigs the same proportion varied between $0.00 \%$ and $3.31 \%$. We compared the results of the period 1996 to 1998 with the period of 1999 to 2001. The proportion of the situations with partial fulfilment of animal protection requirements and subsequent necessity to impose veterinary measures increased in cattle from $0.53 \%$ to $0.82 \%$ and in pigs from $0.65 \%$ to $1.09 \%$. The proportion of the situations of failure to fulfil animal protection requirements increased in cattle from $0.00 \%$ to $0.37 \%$, and in pigs from $0.33 \%$ to $1.33 \%$ showing a significant trend towards deterioration of these conditions $(P=0.0406)$. The results obtained by this detailed analysis show that animal protection has not improved in the interval under study. Our evaluation further shows that it is inevitable to continue the supervisory activities by SVA inspectors and to improve all aspects of animal protection as well as amend the standing legislation.

Cattle, pigs, transport, animal protection, surveillance

Loading, transport and unloading of animals cause unusual stress for them. The animals are forced to move, often by means of various painful stimulations, the structure of animal groups is changed and the animals are exposed to considerable physical and emotional stress due to unusual circumstances of the environment (visual perceptions, noise, smells, changes in temperature, humidity and other components of microclimate, changes of the properties of floor, movements of the vehicle, changes in the centre of gravity, vibrations, changes in feed and water supply and other unusual circumstances). This leads to changes in behaviour and in physiological indices including biochemical and physiological changes which can be observed and which also influence animal products. Therefore the conditions of animal transport are controlled by legal regulations which are based on scientific knowledge and experience. Thus the most prominent forms of cruelty, suffering and injury of the animals are limited as well as the cases of death during transport (Grandin 2000). However, the fulfilment of the legal regulations has to be inspected and enforced if necessary. According to Texdorf (1993) the systematic surveillance of animal protection should be guaranteed 
by veterinarians. Troeger (1996) emphasised the necessity of an appropriate legal framework for the area of animal transport. Similarly, Sojka (1992) considered legal regulation of animal transport to be a very important aspect of animal protection, especially with regard to long-distance shipments. The regulations of the European Union prescribe higher standard of the means of transport for the transport of animals exceeding 8 hours. For instance Kettlewell et al. (2001) developed a prototype of a ventilation system inside the vehicle which is independent on its movement. This system was confirmed as suitable for the transport of pigs in the European Union. Meyen (2000) reported that the numbers of animals transported abroad from Germany are 4.1 million of pigs, 0.6 million of calves and 0.3 million of adult cattle. The same author also underlines the fact that the improvement of the conditions for animals in transport had been initiated by EU regulations in 1990.

Troeger (1965) reported that the parameters that influenced animal welfare and the quality of products of cattle and pigs included the equipment for loading and unloading, vehicle type and equipment, density of transported animals, time of transport and way of driving. According to Fischer (1995) the transport causes always stress for cattle and pigs, since numerous stressors are present. The influence of long-distance transport (10 to 15 hours) of cattle on biochemical indices (for instance on cortisol concentrations) was studied by Warriss et al. (1995). The authors have shown that castrated bulls were losing weight during transport. On the basis of biochemical indices detected and subjective observation the authors do not recommend to exceed the period of 15 hours in transport of cattle. Similarly Tadich et al. (2000) reported that the transport of cattle exceeding 36 hours was not appropriate with regard to animal protection requirements. This conclusion was supported by the fact that increased blood concentrations of cortisol and glucose were detected until the time of slaughter. Tarrant et al. (1992) studied the influence of density of transported bulls on behaviour, haematological and biochemical indices and meat quality. After a 24-hour transport of bulls they detected increased levels of cortisol, and glucose, increased red blood cell and neutrophil counts and decreased numbers of lymphocytes and eosinophils. Numbers of bruises increased with higher numbers of animals loaded. The authors concluded that the density of animals in transport exceeding $550 \mathrm{~kg}$ per sq $\mathrm{m}$ is unsuitable for slaughter bulls. Gallo et al. (2000) found that the transport during the period of $24 \mathrm{~h}$ leads to higher losses of live weight, increased numbers of bruises and more animals recumbent after falling down than during shorter trips of 3, 6 and $12 \mathrm{~h}$. It was also found that transport may increase the occurrence of DFD meat. Villarroel et al. (2001) examined critical elements in cattle transport in Spain with regard to animal protection. The authors found appropriate equipment and time of loading. However, only few staff members had special training and many of them used electric devices to handle the animals. The transport took on average $3.5 \mathrm{~h}$. However, in cases of international shipments the distances and the duration of transport were considerably longer (for instance in cases of shipments to Italy). The protection of against the influence of climate was insufficient. There were no inspections carried out in order to prevent damage to the animals and the equipment of the vehicles was not inspected either.

Steinhardt (2001) compared the values of heart rate, plasma cortisol and other parameters in calves prior to, during after the transport. The author reported increased heart rate in the calves during loading and in the beginning of transport. Plasma cortisol was increased after transport in calves and other changes were also found in the indices of the internal environment of the animals. Grig or et al. (2001) observed calves during transport which consisted of two trips of nine hours each. The calves in transport spent less time lying and had higher plasma cortisol values than the calves in control group.

Selected blood indices of sheep in transport were evaluated by Broom et al. (1996). 
During $15 \mathrm{~h}$ of transport the authors collected blood from sheep at 30-minute intervals. They found that loading and the beginning of transport increased in particular cortisol levels and heart rate. Similar results were presented also by Know les et al. (1995) who reported increased heart rate, plasma cortisol and glucose levels due to stress at loading and during the initial phase of transport. The weight of the sheep decreased with prolonged transport. Cockram et al. (1996) studied the influence of space available during transport upon the behaviour and physiological indices in sheep. The authors concluded that the area of $0.22 \mathrm{sq} \mathrm{m}$ per animal could not be recommended as sufficient for the sheep weighing $35 \mathrm{~kg}$. The area of minimum $0.27 \mathrm{sq} \mathrm{m}$ per animal may be sufficient to enable the sheep to lay down during transport. Increased heart rate and plasma cortisol levels were considered to be the indicators of stress in the sheep during transport. These values were higher than in the sheep that were not transported. Parrott et al. (1999) implanted a biotelemetrical device for measurement of internal body temperature into four young ewes and four rams. They reported that loading of animals and transport of $2.5 \mathrm{~h}$ increased their internal body temperature that remained increased for several hours. The authors concluded that the increased body temperature and the changes in temperature cycles indicated stress and compromised well-being of the animals. Parrott et al. (1998) also monitored heart rate and concentrations of cortisol, prolactin, and catecholamines during loading and transport of sheep. They found that during loading the heart rate increased but cortisol concentrations remained unchanged. However, during transport the concentrations of plasma cortisol increased and reached a maximum within two hours. The authors assumed that in sheep the transport itself caused more stress than the process of loading itself. Jack son et al. (1999) and Cockram et al. (2000) studied the behaviour of sheep, especially with regard to lying and consumption of hay and water during the transport and afterwards. Cockram et al. (1999) reported that during a 16-h transport sheep were lying less than animals that were not transported. Stress in sheep with regard to their transport in socially mixed groups was studied by Hall et al. (1998a). Hall et al. (1998b) also studied the influence of noise and vehicle movement on the behaviour of the sheep and their biochemical indices of stress. The authors found that the movement of the vehicle may cause discomfort for the sheep, especially in the situation when density of the sheep is lower (the area of $0.41 \mathrm{sq} \mathrm{m}$ per one sheep). The noise from the environment did not affect their biochemical indices. Kent (1997) reported that transport was a multifactorial stressor for sheep. If they are stressed especially at the beginning of the journey, they will soon adapt to the situation, provided they have sufficient area (more than $0.25 \mathrm{sq} \mathrm{m}$ ) available for lying.

Transport stress in goats was described by Nwe et al. (1996). These authors studied the influence of a 6-h transport on plasma concentrations of catecholamines, cortisol, glucose and on the eosinophil count. During transport of goats they recorded different manifestations of nervousness and excitement. The concentrations of plasma what increased within $30 \mathrm{~min}$ after the beginning of the transport. Plasma cortisol was increasing during the first hour of transport while plasma glucose was increasing during the first three hours of the transport. Eosinophil count decreased immediately after the beginning of transport and reached minimum values at the end of the transport. Their results showed that the crucial stage of the transport with regard to transport stress in goats was its initial period. Afterwards the adaptation mechanisms began to become effective and to reduce manifestations of transport stress.

Warris (1998) reported that during transport pigs experienced physical and emotional stress. Their weight decreased. The concentration of catecholamines and cortisol increased as well as theeir heart rate. Other indices of the internal environment were also changing and the animals might even die. The stress was influenced by genetic predisposition of the 
animals, mode of handling, density of loading, ambient temperature and by other factors as well. Lambooy and Engel (1991) also studied the influence of animal density, ventilation and sprinkling the animals during $25 \mathrm{~h}$ of transport in pigs. The influence on animal well-being and on meat quality was observed. Interactions between animal density, ventilation and sprinkling of the pigs during the transport and several meat quality indices were found. Based on the results of this work they recommended a maximum transport density of $232 \mathrm{~kg} / \mathrm{sq} \mathrm{m}$ in order to ensure animal well-being and meat quality. According to Gade and Christensen (1998) the density of the pigs loaded for transport had only little influence on blood indices and meat quality in slaughter pigs. However, the influence of density upon the behaviour of the pigs during the transport was considerable, as well as upon different damages to the skin suffered during the transport. The relation of animal well-being and meat quality in the pigs was emphasised by Schutte et al. (1994). The authors proposed penalties for the violation of animal well-being during the transport.

Table 1

Numbers of inspections, veterinary measures imposed and cases of total failure to fulfil the requirements or the protection of cattle, sheep, goats and pigs in transport

\begin{tabular}{|c|c|c|c|}
\hline & $\begin{array}{l}\text { Numbers of } \\
\text { inspections }\end{array}$ & $\begin{array}{c}\text { Numbers of } \\
\text { veterinary measures }\end{array}$ & $\begin{array}{l}\text { Cases of failure to } \\
\text { fulfil the requirements }\end{array}$ \\
\hline \multicolumn{4}{|l|}{ Cattle } \\
\hline 1996 & 54 & 0 & 0 \\
\hline 1997 & 287 & 1 & 0 \\
\hline 1998 & 410 & 3 & 0 \\
\hline 1999 & 416 & 0 & 0 \\
\hline 2000 & 481 & 5 & 4 \\
\hline 2001 & 444 & 6 & 1 \\
\hline \multicolumn{4}{|l|}{ Sheep } \\
\hline 1996 & 14 & 0 & 0 \\
\hline 1997 & 7 & 0 & 0 \\
\hline 1998 & 3 & 0 & 0 \\
\hline 1999 & 13 & 0 & 0 \\
\hline 2000 & 15 & 1 & 1 \\
\hline 2001 & 11 & 0 & 0 \\
\hline \multicolumn{4}{|l|}{ Goats } \\
\hline 1996 & 7 & 0 & 0 \\
\hline 1997 & 4 & 0 & 0 \\
\hline 1998 & 6 & 0 & 0 \\
\hline 1999 & 10 & 0 & 0 \\
\hline 2000 & 20 & 0 & 0 \\
\hline 2001 & 9 & 0 & 0 \\
\hline \multicolumn{4}{|l|}{ Pigs } \\
\hline 1996 & 45 & 1 & 1 \\
\hline 1997 & 233 & 1 & 1 \\
\hline 1998 & 337 & 2 & 0 \\
\hline 1999 & 446 & 1 & 0 \\
\hline 2000 & 414 & 4 & 3 \\
\hline 2001 & 423 & 9 & 14 \\
\hline
\end{tabular}




\section{Materials and Methods}

Transport of cattle, sheep, goats and pigs in the Czech Republic during the period of 1996 to 2001 was monitored with regard to animal protection against cruelty. The inspectors of district offices of the State Veterinary Administration carried out inspections of the animals in transport and means of transport. Each inspection was assessed and categorised as follows: (1) animal protection requirements fulfilled, (2) animal protection requirements partially fulfilled and veterinary measures to improve the protection of animals imposed, (3) failure to fulfil animal protection requirements. The numbers of veterinary measures were determined as well as the numbers of unfulfilled requirements in different years of the study. Furthermore the numbers of the inspections, veterinary measures imposed and cases of failure to fulfil the requirements for the protection of cattle, sheep, goats and pigs during the periods 1996 to 1998 versus 1999 to 2001 were determined in order to evaluate recent changes in the conditions of animal protection. The results were statistically evaluated using $\chi^{2}$ test and the computer software Unistat.

\section{Results}

Table 1 shows total numbers of inspections, numbers of cases when veterinary measures for the improvement of animal protection of cattle, sheep, goats and pigs were imposed, and numbers of cases of failure to fulfil animal protection requirements for cattle, sheep, goats and pigs. The results indicate that the necessity to impose veterinary measures to improve the level of protection in cattle varied between $0.00 \%$ and $1.35 \%$ of the total number of the inspections carried out. In sheep only one such case was recorded and in goats no such case occurred. In pigs it varied between $0.22 \%$ and $2.22 \%$ of the total number of the inspections carried out. The proportion of failures to fulfil animal protection requirements in cattle varied between $0.00 \%$ and $0.83 \%$ of the total number of inspections carried out. In sheep a single case was noted, and in goats no such situation was recorded. In pigs this proportion varied between $0.00 \%$ and $3.31 \%$.

Table 2 shows total numbers of inspections, numbers of cases when veterinary measures

Table 2

Comparison of the data on the transport of cattle, sheep, goats and pigs (total number of inspections, number of cases when veterinary measures were imposed, number of cases of total failure to fulfil animal protection requirements) between the two periods

\begin{tabular}{|c|c|c|c|c|c|}
\hline & \multirow{2}{*}{$\begin{array}{c}\text { Numbers } \\
\text { of inspections }\end{array}$} & \multicolumn{2}{|c|}{$\begin{array}{l}\text { Veterinary } \\
\text { measures }\end{array}$} & \multicolumn{2}{|c|}{$\begin{array}{l}\text { Cases of failure to fulfil } \\
\text { the requirements }\end{array}$} \\
\hline & & Number & $\%$ & Number & $\%$ \\
\hline \multicolumn{6}{|l|}{ Cattle } \\
\hline 1996 to 1998 & 751 & 4 & 0.53 & 0 & 0.00 \\
\hline 1999 to 2001 & 1341 & 11 & 0.82 & 5 & 0.37 \\
\hline Evaluation & - & \multicolumn{2}{|c|}{$\mathrm{P}=0.4544$} & \multicolumn{2}{|c|}{$\mathrm{P}=0.0939$} \\
\hline \multicolumn{6}{|l|}{ Sheep } \\
\hline 1996 to 1998 & 24 & 0 & 0.00 & 0 & 0.00 \\
\hline 1999 to 2001 & 39 & 1 & 2.56 & 1 & 2.56 \\
\hline Evaluation & - & \multicolumn{2}{|c|}{$\mathrm{P}=0.4291$} & \multicolumn{2}{|c|}{$\mathrm{P}=0.2596$} \\
\hline \multicolumn{6}{|l|}{ Goats } \\
\hline 1996 to 1998 & 17 & 0 & 0.00 & 0 & 0.00 \\
\hline 1999 to 2001 & 39 & 0 & 0.00 & 0 & 0.00 \\
\hline Evaluation & - & \multicolumn{2}{|c|}{-} & \multicolumn{2}{|c|}{-} \\
\hline \multicolumn{6}{|l|}{ Pigs } \\
\hline 1996 to 1998 & 615 & 4 & 0.65 & 2 & 0.33 \\
\hline 1999 to 2001 & 1283 & 14 & 1.09 & 17 & $1.33^{*}$ \\
\hline Evaluation & - & \multicolumn{2}{|c|}{$\mathrm{P}=0.3538$} & \multicolumn{2}{|c|}{$\mathrm{P}=0.0406$} \\
\hline
\end{tabular}


for the improvement of animal protection of cattle, sheep, goats and pigs were imposed, and numbers of cases of failure to fulfil animal protection requirements for cattle, sheep, goats and pigs separately for the periods of 1996 to 1998 and 1999 to 2001. The results indicate that the necessity to impose veterinary measures in order to improve the protection increased in cattle from $0.53 \%$ to $0.82 \%$. In sheep the necessity to impose veterinary measures occurred in a single case only during the second period while in goats no such case occurred in either of the two periods studied. In pigs veterinary measures imposed increased from $0.65 \%$ to $1.09 \%$ of the cases. The proportion of failure to fulfil animal protection requirements increased in cattle from $0.00 \%$ to $0.37 \%$. In sheep there was a single case of total failure to fulfil the requirements for animal protection during the second period while in goats no such case occurred in either of the two periods studied. In pigs total failures to fulfil animal protection requirements increased from $0.33 \%$ during the first period to $1.33 \%$ during the second period. The increase in the number of cases of total failure to fulfil animal protection requirements in pigs was significant $(p=0.0406)$.

\section{Discussion}

When the conditions of well-being of cattle, sheep, goats and pigs in transport are observed, the animals are protected against most significant forms of cruelty, suffering, damage and against death in transport caused by improper handling. The present work is based on the conditions for animal protection as laid down in legal regulations of the Czech Republic. They are close to the conditions stipulated by EU regulations. The legal base for the conditions of animal protection is thus in agreement with the opinions published by Sojka (1992) and Troeger (1996). The legally based conditions contain appropriate scientific and professional knowledge and experience and correspond therefore with the information related to the conditions of transport of cattle published by Tarrant et al. (1992), Warriss et al. (1995), Tadich et al. (2000), Gallo et al. (2000, 2001), Villarroel et al. (2001), transport of calves published by Steinhardt (2001), Grigor et al. (2001), transport of sheep published by Knowles et al. (1995), Broom et al. (1996), Parrott et al. (1998, 1999), Hall et al. (1998a, 1998b), Jackson et al. (1999), Cockram et al. (1996, 1999, 2000), Kent (1997), transport of goats published by Nwe et al. (1996), and transport of pigs published by Warriss (1998), Lambooy and Engel (1991), Gade and Christensen (1998), Schutte et al. (1994). Stipulated conditions must, however, be checked by authorities. In accordance with the opinion of Texdorf (1993), veterinarians in this capacity were involved in the present work. It analyzes how of the conditions of animal protection have been observed and evaluated the numbers of the inspections carried out. Furthermore, the inspections were classified in three groups using the following scale: (1) animal protection requirements fulfilled, (2) animal protection requirements partially fulfilled and veterinary measures for the improvement of animal protection were imposed, (3) failure to fulfil animal protection requirements. The trends of the classification results were analysed within the period of 1996 to 2001. The results showed that even if the legal requirements for animal protection during transport are duly laid down, veterinary corrective measures may be necessary and sometimes even a total failure to fulfil the legal regulations on animal protection during transport occur. A surveillance of the fulfilment of the conditions mentioned above is therefore inevitable. The results of the present work indicate that in cattle, sheep, goats and pigs the conditions of animal protection in transport are violated in several cases per year. There is a significant trend in deterioration of the conditions in pigs. Since no complex study had been published on the numbers of veterinary measures imposed in order to improve the protection of cattle, sheep, goats and pigs, and on the numbers of total failures to observe the requirements on the protection of cattle, sheep, goats and pigs, it was impossible to compare directly the parameters mentioned above. The 
inspections of the conditions for animal transport should be especially focused on loading and unloading of the animals, type and transport equipment, density of loaded animals, duration of transport, rest periods during the transport, way of driving, method of ventilation of the vehicle, feeding and watering of the animals, and on other conditions which are important for the protection of animals in transport, as mentioned by Meyen (2000), Troeger (1996), Fischer (1995), Schutte et al. (1994) and others.

In the literature available to us there was no comparable evaluation done using a similar size of data on supervisory activities aimed at the protection of animals during transport. An important finding emerged from this study, i.e. that the situation in animal protection in our country is not satisfactory as might be believed. It has not improved in the period under study and thus supervisory activities carried out by SVA officers are fully justified. Conditions of animal transport need improvement and the legislation must be further amended.

\section{Přeprava skotu, ovcí, koz a prasat z pohledu ochrany zvířat proti týrání}

Podle kontrol prováděných úředními veterinárními lékaři při dozoru dochází $\mathrm{k}$ porušování podmínek ochrany zvířat při přepravě. Autory proto byla ve vybraných souborech hodnocena přeprava skotu, ovcí, koz a prasat ve stanoveném období 1996 až 2001 v České republice. Každá kontrola byla posouzena podle stupnice: splnění požadavků $\mathrm{k}$ ochraně zviŕat, stanovení veterinárních opatření k zlepšení úrovně ochrany zvířat, nesplnění požadavků k ochraně zvířat. Potřeba stanovení veterinárních opatření ke zlepšení úrovně ochrany skotu se pohybovala $\mathrm{v}$ rozmezí $0,00 \%$ až $1,35 \%$ z počtu provedených kontrol, u ovcí a koz se vyskytla jen ojediněle, u prasat se pohybovala v rozmezí $0,22 \%$ až $2,22 \%$ z počtu provedených kontrol. Nesplnění požadavků k ochraně u skotu se pohybovalo $\mathrm{v}$ rozmezí $0,00 \%$ až $0,83 \%$ z počtu provedených kontrol, u ovcí se vyskytlo jen $\mathrm{v}$ jednom případě, u koz žádném případě a u prasat se pohybovalo $\mathrm{v}$ rozmezí $0,00 \%$ až 3,31\% z počtu provedených kontrol. Porovnali jsme výsledky pro období 1996 až 1998 s obdobím 1999 až 2001. Potřeba stanovení veterinárních opatření k zlepšení úrovně ochrany skotu se zvýšila z $0,53 \%$ na $0,82 \%$, u prasat se zvýšila z $0,65 \%$ na $1,09 \%$, nesplnění požadavků k ochraně skotu se zvýšilo z $0,00 \%$ na $0,37 \%$, u prasat se zvýšilo z $0,33 \%$ na $1,33 \%$ a po statistickém zpracování $\chi^{2}$ testem počítačovým programem Unistat se toto zvýšení bylo prokázáno statisticky významné $\left(\mathrm{P}=0406^{*}\right)$. Z výsledků vyplývá, že u skotu, ovcí, a prasat dochází k porušování podmínek ochrany zvířat při přepravě na úrovni několika případů ročně a že existuje statisticky významný trend zhoršování těchto podmínek u prasat. Předložené hodnocení provedené soubornou analýzou za použití statistiky prokazuje, že není oprávněné tvrzení, že situace v ochraně zvířat při přepravě se v našich podmínkách za sledované období výrazně zlepšila. Prokazuje oprávněnost provádění dozoru a potvrzuje nutnost zlepšení podmínek ochrany zvířat a tím i nezbytné novely právních předpisů.

\section{Acknowledgements}

The work was supported by research grant No. VZ16270004 of the Ministry of Education, Youth and Sports "Research of environmental and ecotoxicological aspects of food chains in agricultural ecosystems in the process of production of raw materials and food of animal origin with regard to the environment of the population".

\section{References}

BROOM, DM, GOODE, JA, HALL, SJG, LLOYD, DM, PARROTT, RF 1996: Hormonal and physiological effects of a 15 hour road journey in sheep: Comparison with the responses to loading, handling and penning in the absence of transport. Brit Vet J 152: 593-604

COCKRAM, MS, KENT, JE, GOODDARD, PJ, WARAN, NK, McGILP, IM, JACKSON, RE, MUWANGA, GM, PRYTHERCH, S 1996: Effect of space allowance during transport on the behavioural and physiological responses of lambs during and after transport. Anim Sci 62: 461-477 
COCKRAM, MS, KENT JE, WARAN, NK, McGILP, IM, JACKSON, RE, AMORY, JR, SOUTHALL, EL, O'RIORDAN, T, MCCONNELL, TI, WILKINS, BS 1999: Effects of a $15 \mathrm{~h}$ journey followed by either $12 \mathrm{~h}$ starvation or ad libitum hay on the behaviour and blood chemistry of sheep. Anim Welfare 8: 135-148

COCKRAM, MS, KENT JE, GOODDARD, PJ, WARAN, NK, JACKSON, RE, McGILP, IM, SOUTHALL, EL, AMORY, JR, McCONNELL, TI, O'RIORDAN, T, WILKINS, BS 2000: Behavioural and physiological responses of sheep to $16 \mathrm{~h}$ transport and a novel environment post-transport. Vet J 159: 139-146

FISCHER, K 1995: Animal transport - effects, weak points, measures. Fleischwirtschaft 75: 790-796

GADE, PB, CHRISTENSEN, L 1998: Effect of different stocking densities during transport on welfare and meat quality in Danish slaughter pigs. Meat Sci 48: 237-247

GALLO, C, PEREZ, S, SANHUEZA, C, GASIC, J 2000: Effects of transport time of steers before slaughter on behaviour, weight loss and some carcass characteristics. Arch Med Vet 32: 157-170

GALLO, C, ESPINOZA, MA, GASIC, J 2001: Effects of 36 hours road transport with or without a resting period on live weight and some meat quality aspects in cattle. Arch Med Vet 33: 43-53

GRANDIN, T 2000: Management and economic factors of handling and transport. In GRANDIN, T. et al. Livestock, handling and transport, CABI Publishing, 2nd ed., Wallingford-New York, pp. 1-9

GRIGOR, PN, COCRAM, MS, STEELE, WB, LE SUEUR, CJ, FORSYTH, RE, GUTHRIE, JA, JOHNSON, AK, SANDILANDS, V, REID, HW, SINCLAIR, C, BROWN, HK 2001: Effects of space allowance during transport and duration of mid-journey lairage period on the physiological, behavioural and immunological responses of young calves during and after transport. Anim Sci 73: 341-360

HALL, SJG, KIRKPATRICK, SM, BROOM, DM 1998a: Behavioural and physiological responses of sheep of different breeds to supplementary feeding, social mixing and taming, in the context of transport. Anim Sci 67: $475-483$

HALL, SJG, KIRKPATRICK, SM, LLOYD, DM, BROOM, DM 1998b: Noise and vehicular motion as potential stressors during the transport of sheep. Anim Sci 67: 467-473

JACKSON, RE, COCKRAM, MS, GOODDARD, PJ, DOHERTY, OM, McGILP, IM, WARAN, NK1999: The effects of $24 \mathrm{~h}$ water deprivation when associated with some aspects of transportation on the behaviour and blood chemistry of sheep. Anim Welfare 8: 229-241

KENT, JE 1997: Stress in transported sheep. Comp Haematol Int 7: 163-166

KETTLEWELL, PJ, HOXEY, RP, HAMPSON, CJ, GREEN, NR, VEALE, BM, MITCHELL, MA 2001: Design and operation of a prototype mechanical ventilation system for livestock transport vehicles. J Agr Eng Res 79: 429-439

KNOWLES, TG, BROWN, SN, WARRISS, PD, PHILLIPS, AJ, DOLAN, SK, HUNT, P, FORD, JE, EDWARDS, JE, WATKINS, PE 1995: Effect on sheep or transport by road for up to 24 hours. Vet Rec 136: 431-438

LAMBOOY, E, ENGEL, B 1991: Transport of slaughter pigs by truck over a long-distance - some aspects of loading density and ventilation. Livest Prod Sci 28: 163-174

MEYEN, K 2000: Practical problems associated with trade in animals. Tierärztl Umschau 55: 438-

NWE, TM, HORI, E, MANDA, M, WATANABE, S 1996: Significance of catecholamines and cortisol levels in blood during transportation stress in goats. Small Ruminant Res 20: 129-135

PARROTT, RF, LLOYD, D.M., BROWN, D 1999: Transport stress and exercise hyperthermia recorded in sheep by radiotelemetry. Anim Welfare 8: $24-34$

PARROTT, RF, HALL, SJG, LLOYD, DM 1998: Heart rate and stress hormone responses of sheep to road transport following two different loading procedures. Anim Welfare 7: 257-267

SCHUTTE, A, VON WENZLAWOWICZ, M, VON MICKWITZ, G 1994: Animal transport and meat quality in pigs. Fleischwirtschaft, 74: 126

SOJKA, K 1992: Transport of slaughter animals. Prakt Tierartz 73: 816

STEINHARDT, M 2001: Reactions of suckled calves to short haul transport by road. Effects on plasma cortisol, biochemical markers, haematology, mineral concentrations and heart rate. Tierärztl Umschau 56: 597-602

TADICH, N, GALLO, C, ALVARADO, M 2000: Effects on cattle of transportation by road up to 36 hours with and without a rest on some blood variables indicator of stress. Arch Med Vet 32: 171-183

TARRANT, PV, KENNY FJ, HARRINGTON, D, MURPHY, M 1992: Long-distance transportation of steers to slaughter - effect of stocking density on physiology, behavior and carcass quality. Livest Prod Sci 30: 223-238

TEXDORF, I 1993: Animal protection and the official veterinarian - a report on experience gained. Fleischwirtschaft 73: 532-537

TROEGER, K 1995: Handling during transport and its effect on product quality. Fleischwirtschaft 75: 415

TROEGER, K 1996: Animal welfare in husbandry, transport and slaughter of farm animals. Fleischwirtschaft 76: 1222

VILLARROEL, M, MARIA, GA, SIERRA, I, SANUDO, C, GARCIA-BELENGUER, S, GEBRESENBET, G 2001: Critical points in the transport of cattle to slaughter in Spain that may compromise the animalsę welfare. Vet Rec 149: 173-176

WARRISS, PD 1998: The welfare of slaughter pigs during transport. Anim Welfare 7: 365-381

WARRISS, PD, BROWN, SN, KNOWLES, TG, KESTIN, SC, EDWARDS, JE, DOLAN, SK 1995: Effects on cattle of transport by road for up to 15 hours. Vet Rec 136: 319-323 